\title{
COVID-19 Induced Changes in Consumer Behavior
}

\author{
Michael Gerlich \\ Anglia Ruskin University, Cambridge, UK \\ Email: michael.gerlich@cantab.net
}

How to cite this paper: Gerlich, M. (2021). COVID-19 Induced Changes in Consumer Behavior. Open Journal of Business and Management, 9, 2425-2451.

https://doi.org/10.4236/ojbm.2021.95131

Received: July 25, 2021

Accepted: September 15, 2021

Published: September 18, 2021

Copyright $\odot 2021$ by author(s) and Scientific Research Publishing Inc. This work is licensed under the Creative Commons Attribution International License (CC BY 4.0).

http://creativecommons.org/licenses/by/4.0/ (c) (i) Open Access

\begin{abstract}
Using literature survey and analysis, this study assessed consumption behavior changes induced by the COVID-19 pandemic and the possibility of retaining them after the pandemic. Financial uncertainty and loss of welfare sources triggered saving behaviors. Some people binged on media products offering anxiety-mitigating and therapeutic benefits. While such behaviors could decrease once the virus is eliminated and its stressors disappear, some routines could continue. Certain values affecting the nature and frequency of consumption could also change, thus increasing the speed of individual customers' habit formation. To make accurate long-term strategic decisions without suffering losses, the restaurant sector and other businesses must adjust to new operational conditions by analyzing changing revenues and possible lasting effects of changing consumer behavior.
\end{abstract}

\section{Keywords}

Consumer Behavior Changes, COVID-19, Economic Changes, Psychological Behavior

\section{Introduction}

Since the outbreak of the Coronavirus Disease 2019 (COVID-19) pandemic early last year, it has affected every possible aspect of life. Its pernicious impact did not spare even consumption, whose determinants were affected, including people's health and financial well-being, which have suffered paradoxically, despite pandemic containment efforts. In the study by Cariappa et al. (2020) on an Indian sample, $59.53 \%$ of the respondents pointed to the lockdown having impacted them, varying from mild to severe in most cases. While 3.3\% described themselves as having been severely affected, an estimated $10 \%$ reported moderate to severe impact. This impact was predictable, given that the economy underper- 
formed owing to the lockdown, as shown by Verschuur et al. (2021) study, whose application of empirical vessel-tracking data found that the international maritime trade suffered losses between $7 \%$ and $9.6 \%$ in the first eight months of 2020 alone, equivalent to $\$ 225$ - 412 billion in value losses. Since consumption was a variable linked to people's incomes that were affected, it did not remain static, but fluctuated. Cariappa et al. (2020) reported that $92.01 \%$ acknowledged a recognizable change in their shopping behaviors. An estimated $90 \%$ of respondents associated this change with infection risks and the strict lockdown. When it comes to actual changes, Kumar and Abdin's (2021) India-based study predicted the persistence of the essentials-only consumption pattern that emerged following the spell of panic-buying, corroborated by the majority of respondents' inputs. These comprise just a few of the several studies that show the pandemic's impactful nature and confirm that there has been a change in consumer behavior. The change occurs based on mechanisms, such as classical and operant conditioning, as well as the social learning and risk perception theories, which can determine the permanence of people's behavioral shifts, in terms of their consumption in the wake of the pandemic.

Hence, this study's major goal is to identify whether consumer changes are induced by the pandemic and measures necessitated by it, such as lockdowns, or whether the complexion of the consumer market is changing in terms of preferences and buying enthusiasm or intensity.

The following part of the article will introduce the research questions and research approach.

\section{Research Questions and Research Approach}

Based on a wide set of findings, the following issues were derived and examined:

1) whether saving behavior is a temporary phenomenon made relevant by the persistent pandemic;

2) whether COVID-19 has had a reverse impact by boosting consumption behaviors, and

3) whether such behaviors are here to stay;

4) the trend of excessive media consumption and panic-buying, including their persistence against all odds;

5) the shift to home cooking and the prospects of the pre-pandemic business pace being resumed in the restaurant sector;

6) the changes of values - an essential issue-in the face of an existential crisis that can end the era of consumerism;

7) the chances of new consumption habits being retained.

This study used the literature survey method that involved searching for literature deemed relevant, assessing their sources, identifying key debates and themes, transferring the information selected, and its thematic synthesis. The method of analysis made it possible to draw inferences from the secondary literature compiled. This study is mainly based on secondary research in the form 
of a literature review and published statistics. Its findings have turned out to be contrary to the major limitations encountered in the course of this study, including the relative deficit of quality sources. A literature review can broadly be described as a more or less systematic way of collecting and synthesizing previous research (Baumeister \& Leary, 1997; Tranfield et al., 2003). An integrative review approach (Torraco, 2005) has been used for the purpose of combining different perspectives.

\section{Results}

\subsection{Saving Behavior-A New Behavioral Mainstay?}

When a crisis having adverse financial implications presents itself, many people tend to adopt saving behaviors. Jin et al. (2021) pointed out that based on an inspection of individuals' psychology, it was possible to assert that consumers generally put their enhanced savings on display in the course of a pandemic due to perceived risks, while their spending was inversely proportional to their volume of savings/willingness. However, the study by Jin et al. (2021) did not link people's saving behaviors to their staying at home, thus reducing the relevance of individual acquisitions, including in the fashion category. It was unlike Davenport et al. (2020), who attributed it to lockdown-induced forced saving, whereas Christelis et al. (2020) applied the concept of precautionary savings. Sometimes, researchers tend to point to saving by using consumption and spending. Coffey et al. (2020), for example, talked about a decrease in consumption associated with social distancing and business closedowns, while Baker and Yannelis (2017), Baker (2018), Gelman et al. (2020), and Garmaise et al. (2020) shared an understanding that consumers respond to adverse shocks through a decrease in spending owing to the onset of falling expectations concerning future income prospects, financial constraints, and enhanced uncertainties (cited in Chronopoulos et al., 2020: p. 6).

Likewise, Jin et al. (2021) did not provide any accurate prediction of how the spending situation would unfold in the period following the suppression of the virus. This fact indicates that studies centered on the long-term impact of the COVID-19 severity are yet to focus on the spending and saving behavior of people following the culmination of the global pandemic. This observation seems valid, as there are plenty of media reports in circulation. Hannon's (2021) article in the Wall Street Journal stated that consumption revival could accelerate the economy but refrained from making specific predictions. However, Jim Glassman (2021), JP Morgan's Managing Director and Head Economist, sounded more certain that many consumers were well-placed to step up spending once the pandemic dies down. This prediction makes sense, as Slovic et al. (2004) regarded the perception of risks as a situational psychological variable (cited in Jin et al., 2021). Consequently, if the situation changed, the perception of risks by an individual would also change (Jin et al., 2021). Slovic (2000) cited

the risk perception theory, which can lend validity to this prediction. Based 
thereon, the closer a disaster is, the higher will be the perception of risks (cited in Jin et al., 2021). Arias et al. (2017) also defined the proximity of threats as a factor that influences the perception of risks among people exposed to potential threats. The same can be said of Kinateder et al. (2015), who correlated the extent of proximity with that of intentions and preparedness, which virtually implies risk perception, as people would not prepare themselves if they did not sense the proximity of danger. Based on this theory, Jin et al. (2021) predicted that the easing of COVID-19 will eliminate individuals' risk perceptions, as well as its impact on consumer spending and saving behaviors. Hence, it was concluded that the impact of the pandemic's severity on consumer spending and saving behaviors would be short-term, without transcending the chronological confines of the pandemic (Jin et al., 2021). Still, one can disagree regarding the probability of such behavior changes once the virus has been eradicated.

The problem is that COVID eradication is not a spatially homogeneous and simultaneous process or achievement, that gets rid of the virus with one wave of a magic wand. No such outcome can be expected as some countries will fare worse, given the low rate of vaccinations, whether it is due to logistic, corruption, or other factors. Even states scoring high on vaccinations may have some pockets of infection left to battle, as a large number of people refuse to get vaccinated and even fully vaccinated citizens still can get infected and can transmit the virus. In any case, just as the governments were unable to block the penetration of the virus in early 2020, the pandemic will continue at least temporarily, as economic globalization and the circulation of goods will persist, if not grow in intensity, being driven by economic losses and labor force decimation by the virus. Given that, media and healthcare ministries are mostly transparent, unless in authoritarian states, people will know if the infection is still persisting in some pockets. If so, they may not have fears, which leads them to abandon their reduced spending and enhanced saving behaviors.

There are further arguments to challenge the view of behavioral rollbacks and the resumption of usual spending patterns. Another problem is that COVID-19 has ravaged many economies worldwide. Gorbiano (2020) offered very telling evidence of its impact, referring to Sri Mulyani, the Minister of Finance of the Indonesian Republic, who predicted that the pandemic would lead to the ranks of the poor being replenished by 1.1 to 3.78 million people, while 2.9 to 5.2 million were expected to enter the category of the unemployed. The first figures in the datasets represent the blue-sky scenario of minimal projected adverse outcomes (cited in Supriatna, 2020). Studies offering similar figures are aplenty, as are those detailing losses sustained by different industries around the world, including that by Ozili and Arun (2020) who pointed to $\$ 820$ billion in losses faced by the business travel industry, which is a prediction made as early as the beginning of the outbreak. General figures, too, rationalize the unemployment and poverty trends that seem bound to continue, and are none the more optimistic, given that, Credit Suisse (2020) showed that the debt ratio as a percentage of 
GDP had climbed to around $28 \%$ in Spain, relative to about $14 \%$ observed in 2008-2009.

People do not reside in an information vacuum; they will be aware of how the economic situation unfolds, given the high odds of poor development and their welfare being directly dependent on economic health. Hence, they will not struggle to understand that the economies around the world will have no way of absorbing the large labor force once the pandemic is over, and their economies are gradually getting back on track. Even if employed, people may not rest easy about their financial security, as the labor surplus can feed the temptation of employers to lower pay rates in the knowledge that galloping unemployment will force talents on the payroll into accepting smaller paychecks if only to cling on to their positions. There being no governmental intervention, this abuse can actually take place, leaving people fearing about their being fired. The long-term impact of COVID-19 that can make its presence felt with time, gives employers reasons to terminate their employees, despite their having recovered from the crisis. Its long-term health impact that can interfere with people's ability to retain their jobs has already been well-documented. Del Rio et al. (2020) described clinicians as observing and reading reports of patients with acute symptoms and even considerable end-organ dysfunction, following the SARS-CoV-2 infection. Among the organs affected were the brain, lungs, and heart, which are ascribed to direct tissue invasion by the virus.

\subsection{The Buying Spree-Why the Pandemic Can Become a Boon for Some Producers/Retailers?}

Conversely, producers and businesses can gain from the pandemic in terms of consumption. According to Jin et al. (2021), the pandemic can enhance individuals' risk perception and stimulate saving versus spending behaviors. It is believed that due to a desire to ease their anxiety, many individuals would consume before they save. This consumption behavior correlates well with the existing academic literature. Hill et al. (1997) argued that people understand life to be finite in the face of a death threat, which prompts consumption, and a decrease in savings (cited in Jin et al., 2021). According to Hill et al. (1997), the propensity toward spending/saving behavior depends on materialism-the value orientation of individuals demonstrating the degree to which they perceive the purchase of material ownership as an indication of accomplished life objectives (cited in Jin et al., 2021). Belk (1985), Richins and Dawson (1992), and Chan and Prendergast (2007) further explained that materialistic persons seek to secure happiness and success by focusing on, and pursuing material wealth and property acquisition (cited in Jin et al., 2021). Unsurprisingly, Ger and Belk (1996) acknowledged that such highly materialistic individuals always tried to own more things than others, even when perceiving the pandemic's risks.

Another possible attention-worthy explanation is the therapeutic property of shopping, that Atalay \& Meloy (2011) referred to as the retail therapy, in which, 
individuals attempt to cheer themselves via the acquisition of self-treats. Negative moods serve as a driving force of the consumption behavior that results in a greater rate of buying and the acquisition of unplanned treats. Mood improvements, without the feelings of guilt and regret, which follow such unplanned buying sprees, is a lasting positive effect of this therapy aimed at mood adjustments (Atalay \& Meloy, 2011). The pandemic brings many restrictions to life, at the very least, to say nothing of its lethality and the consequent traumatizing impact. Since people have mood swings, buying becomes a rational therapeutic means and a response to mood declines. Gitimu and Waithaka (2019), who concurred that retail therapy could improve bad moods, pointed to its ability to fill life with value. It does so by enabling engagement in meaningful behaviors (Gitimu \& Waithaka, 2019). Yet, it may be short-lived, in that, it gives meaning only during the activity's time span. Moreover, this therapy can have even greater utility, and Lee (2015) generalizes its application range by claiming that it repairs negative feelings, thereby implying their multitude.

Now, it would be rational to respond to the findings retrieved. When it comes to the viability of the behavior, therapeutic buying seems driven by external stressors associated with the pandemic. While its elimination can remove the stressors, which will make the buying behavior no longer necessary, what lies ahead is not as simple. The impact of the pandemic has ripped apart national economies, causing great havoc. Waitzkin (2020) confirmed its destructive impact, using the concept of capitalism collapse, and so did Barlow et al. (2021) by pointing to the global trade collapse, which will shatter financial security and retain uncertainty. Similarly, the Financial Stability Board (2020) is among the multiple sources confirming economic uncertainty induced by the pandemic. Hence, the therapeutic utility of buying will stand, albeit to a lesser degree, as pandemic dissipation will remove a portion of stressors, while the remaining ones will be on the ebb due to gradual recovery. Although relevant, the very presence of external stressors associated with financial instability will arguably cripple/limit the ability of people to pursue such buying behaviors.

Additionally, economic winners of the pandemic were online shopping platforms like Amazon (which increased its sale by up to 200\% (Dastin \& Rana, 2021) and supermarket chains (Mattinson, 2021).

\subsection{Binge-Watching and Panic-Buying as Juncture-Induced Behavioral Trends or the New Reality?}

While on a consumption spree, people can hoard or otherwise access large amounts of media and literature of a certain genre that can offer a coping potential. According to Lucken (2021), at a time when the COVID-19 pandemic was raging, strong binge-watching gained the status of an acceptable pastime. The time spent in this fashion ceased being regarded as time that was wasted (Lucken, 2021). Perhaps, for people who have temporarily shed the stigma of time-wasting (which usually comes with excessive watching), the collateral feel- 
ing of shame feeds the enhanced consumption trend. Hence, the pandemic gave this consumption intensity an air of legitimacy, apart from incentivizing its choice, as a way to fill the free time vacuum when some employers were forced into coming to a standstill. The volume of reading was not the only activity to have changed since the pandemic's outbreak, given that, the complexion of the consumption market too, had changed. After the COVID-19 outbreak that came to be classified as a global pandemic, there has been a shift in consumer preferences in the category of books. Although not necessarily seismic, this trend is worth examining.

An overview of the literature consumption trends by Gamerman (2020) showed an increase in the demand for books on pandemics. Thus, for example, based on the data from NPD BookScan, the first two months of 2020 saw the trade paperback sales of Stephen King's "The Stand" rising by $25 \%$ despite its having been first printed as far back as 1978, while sales of the hardcover of the novel-centered on a weaponized fly decimating nearly all the humans and animals around the world-increased threefold during the comparable period. Many readers were making efforts to compare the book with the present-day virus, so much so that the author himself saw it fit to take to Twitter, with an eye to getting the idea refuted. When it comes to other books on pandemics, the sales of "Station Eleven" by Emily St. John Mandel soared by 50\%, while "World War Z" experienced a lesser, albeit significant growth of 33\%, which occurred in the first two months of 2020 . Overall, print sales of adult nonfiction on contagious illnesses rose by $52 \%$ (Gamerman, 2020).

Another creative product, albeit in the cinematic domain, has soared in popularity after the onset of the pandemic, although it was produced earlier. As reported by Sperling (2020), the movie “Contagion” from 2011 was listed as \#270 in the catalog of Warner Brothers, but from the end of December 2019 to the beginning of 2020, it made its way to $\# 2$. That the film ranked second, with only the Harry Potter film ahead of it, means that no other apocalyptic films could beat it, while some likely films could not so much as come close to stirring up as much interest. McGuire (2021) offered a causal insight into this trend, which can shed light on why there is variability in the popularity of the genre, whose demand seems to be peaking. Apparently, the movie was an instant hit even on its release date, grossing $\$ 8$ million when out in theaters and dominating the weekend. To decipher its success, the study draws parallels with other films of the same genre only to find a popularity clue in the way the film ended, as compared with other alternatives in this genre. The disease did not lose its intensity mercilessly with the change of seasons, as compared with early plague narratives. Instead, a happy ending was achieved by designing a vaccine (McGuire, 2021).

In all likelihood, the film gained popularity, or at least maintained its momentum, when it became obvious that the COVID-19 pandemic is not a seasonal epidemiological phenomenon, and that it will not die down until conquered via vaccination (this presumption is somewhat speculative as there is no tracker 
of film popularity). It could be that its proximity to the "Contagion" storyline involving the vaccination-assisted end of the disease (which became manifest as COVID-19 raged on), that can have made the movie more popular than others. The relevance of virus-centered apocalyptic movies was lost to observations made by people on COVID-19 not being seasonal in nature. Moreover, the film can invite further parallels, including its etiology or origin-based similarity, along with symptomatic commonness, its import from China (Hong Kong), quarantines, and panic-buying, to name but a few. In retrospect, since to some extent, the film looks like a simulation of what is to happen in the future, its realism, on which, many other apocalyptic movies lost, is what was likely to have made it the most popular in its genre, at least, at the time of writing. Apart from the film serving as a behavioral manual in its own right by showing how to behave during a pandemic, it could have been soothing to its audience by portraying that a near-similar virus could be conquered, and that the vaccine which the people are presently awaiting would also work. Thus understood, the film's fear-reducing leverage allows people to cope with panic unassisted, that is, without human psychologists being involved.

It is not that the genre was not popular before the virus; it is just that it gained significant momentum. Now, it remains to be understood what it was that got people to increasingly switch to the apocalyptic genre by choice. One of the major things that COVID-19 has done is changing people's lives, at least in the foreseeable future. Being lethal and highly contagious, the pandemic has made it necessary for people to change their lifestyles in a way that left them lacking access to their favorite entertainment and pastime options, which could not but result in frustration and anger buildup. While overwhelmed by such emotions, the body is likely to face the need to shed the adverse emotions, and aggression venting could be the way, to do that which is within reach; still, it seems counterproductive based on what researchers have had to say in this regard. While Kirsh (2019) has acknowledged the widely held conviction of acting out, ruminating, and venting being instrumental in the release of aggressive sentiments and pent-up anger, no backing for such beliefs can be identified in empirical data. Far from supporting the catharsis effect of this way of coping with negative emotions, scholars often suggest otherwise. Put differently, rather than decreasing aggression, the release of pent-up energy by yelling or hitting objects does little, other than enhancing aggressive sentiments and thoughts. Thus, an alternative to counterproductive anger wreaking emerges, as some people reportedly entertain and share an understanding that cathartic behaviors are beneficial, and hence, are in search of violent media, including zombie apocalypse tales (Kirsh, 2019). This interpretation falls in line with the stance of other researchers, including Bushman (2002), who agreed that media violence offered an outlet for aggressive drives based on the catharsis model (cited in Ferguson, 2010), as well as Mack and Ott (2010) and Helfgott (2018), who regarded violent media catharsis as that which enabled engagement in fantasy aggression by viewers, re- 
moving the relevance of adopting aggressive behaviors.

Aside from venting negative emotions in a non-violent way, people may increasingly resort to such media to achieve another essential goal. According to Kirsh (2019), the portrayal of violent fantasies, including those in video games, movies, television, and books, can assist people to calm themselves in the face of real-life violence, consequently diminishing their fears and anxieties. Being shocked by an image in the safe context of fantasy can allow people to avoid being shocked in reality (Kirsh, 2019). This observation is as close as the researcher came to explaining how anxiety reduction could be achieved, to enable coping. Somewhat similar is the view of Srivner and Christensen (2021), who claimed that some of the horror movies feature decreased anxiety, while concurrently building resilience skills, including the cognitive ones that enable coping with fear and anxiety. Lincoln (1998) too, offered a brilliant rationale behind the popularity of such movies: they indicated that a cataclysmic change resulted in weak people being exalted and mighty ones being humbled (cited in Hamonic, 2017). Yet, this revanchist driver addressing frustration over the socioeconomic gap is universal, or such that, may not necessarily gain particular relevance during crises like the pandemic (although adverse welfare shocks can aggravate frustration). Actually, it must be that the perception of the current harsh reality can become easier when genre viewers compare it with that portrayed in such horror films. Current issues can appear dwarfed, in relation to those faced by cinematic characters; hence, life is easier to live, even despite, there being a large-scale pandemic and collateral issue.

There is actual evidence of the fear-reducing potential of exposure to violent media content, according to Kirsh (2019), and a case in point, visualizing the trend, comes from the Columbine massacre. Andrew, whose relation to the tragic event was not identified, was said to have become anxiously preoccupied with school shootings. Still, his fears associated with this type of traumatizing events were rather quick to abate as a result of his watching a gory and violent movie called "Natural Born Killers". Consequently, the consumption of zombie-themed entertainment could have comparable outcomes. Still, it was also noted that the ability to have the emotional adjustment effect was contingent on the characteristics of individuals, and the gratifications sought by them, in the process of such media consumption (Kirsh, 2019).

It is good that people have more sense than to resort to aggressive outbursts; still, the question is whether the consumption trend will stand going forward, particularly when the pandemic draws to a close. On the one hand, the negative stressor that feeds the watching impulse will be mostly gone by then. The very relevance of watching such movies can fall apart, with old preferences dusted off by consumers, including comedies. On the other hand, the reality may be more intricate than presumed. When the pandemic ends, at least some people may still stick with the apocalyptic genre, for example, those who might have developed sympathy for a certain character, such as Rick Grimes from the TWD un- 
iverse, or another protagonist from the crew of survivors, or an antagonist like Negan, although the reasons for their continued preference could be different. An important impact of the pandemic is to ensure the exposure of consumers, who would not otherwise taste the genre to the product. Once they get to do so, while in the midst of the pandemic, it could create a testing imperative or impulse, and they can become fans of that genre, never to abandon it. With regard to reasons, aside from the personal emotional attachment to any character, there can arise positive associations with a book/film since the new-gained horror genre consumption habit allowed reducing negative conditions and became a coping means.

Here, a behavioral theory, such as classical conditioning, may be at work. Berkley and Kaplan (2019), who explained the mechanism also identified respondents of Pavlovian conditioning-a learning procedure, in which, a previously neutral stimulus was paired with a powerful stimulus. Based on the learning process that stems from pairing, the neutral stimulus starts evoking a response that is associable with that elicited by the powerful stimulus (Berkley \& Kaplan, 2019). In the current context, the apocalyptic genre was a neutral stimulus that was not used to incentivize a positive outcome, such as the reduction of negative emotions, until consumption. This first-ever consumption experience, when followed by emotional state adjustments, is likely to have led many to develop positive associations with what previously left them indifferent, with the result that the genre will be sought if only to achieve the same emotionally stable conditions that enhance satisfaction and happiness. Still, this quest can be conditioned, that is, the relevance and frequency of the genre's consumption may depend on the presence of negative emotions, although many viewers and readers may consume it, regardless of finding some enjoyment in aspects beyond its emotional impact, which can be the narrative, characters, etc. Hence, the habit of reading/watching the apocalyptic genre that sometimes wanders into the horror category may persist, proving itself more viable than growling and scratching characters in the films and TV series now preferred more than earlier.

People who indulge in binging are currently not only hooked on media products and literature, but also on groceries and other goods, which are still high on the agenda of at least some people, who would just as soon stock up on them, rather than run the risk of missing out on critical commodities. The study by O'Connell et al. (2020) confirmed the panic-buying trend by examining other researchers' findings. For example, Keane and Neal (2020) found a spike in searches for terms like "toilet paper" based on Google search data (cited in O'Connell et al., 2020), while Baker et al. (2020), Cox et al. (2020), and Hacioglu et al. (2020) pointed to a significant increase in grocery spending (cited in O'Connell et al., 2020). In digital terms, grocery store sales experienced a 77\% upswing during a single week in March 2020 itself (Yoon, 2020). Apparently, high prices build an impression of commodities being in short supply, which makes individuals panic. Whilst in this mode, the judgment of individuals gets 
clouded, which leads to irrational consumer choices, such as stocking up. The role of high prices is likely, as confirmed by Cariappa et al. (2020), who pointed to Indian respondents, of whom $75.31 \%$ faced an increase in food prices and acknowledged limited access to food markets, while Dastagiri (2019) acknowledged the influence of prices that may act as price signals or the information conveyed to producers and consumers.

However, as with the apocalyptic genre of literature and cinema, the removal of a stressor, such as the pandemic, will render stocking useless, as consumers will realize that there are no longer any reasons for logistic and supply disruptions over the standstill of production facilities, which is normally responsible for the stimulation of an erratic buying behavior devoid of rationality. Hence, panic-buying is but a temporary issue, barely visible even at this juncture, since the pandemic and its threats have crystallized, with people aware of what to expect, in the sense, that there is no uncertainty as was the case when the world was months into what eventually became a global pandemic. Now that the world has adjusted itself to the new living and operational conditions, uncertainties and the respective fears are too distant to cause the former panic buying, even pending the final eradication of COVID-19.

\subsection{Homemade Cooking-A New Reality? Is There a Life for Restaurants Post-COVID-19?}

Aside from the apocalyptic content, people may take to watching what will allow them to cook wonderful dishes, even in the absence of any previous habit or skills, which has another consumption implication. In 2017, the share of super-consumers who were used to cooking a lot and who loved to do so was only two-thirds of its 1997 level and represented only 10\% of the American population. Cooking virtually experienced the shift that sewing faced in its time, in the sense that what used to be almost everyone's routine was reduced to a hobby enjoyed by a small minority (Yoon, 2020). This analogy has found reflection in many sources, including those by Wolf (2014), who described home sewing and knitting as largely instinct based, and Hua (2018), who confirmed the loss of interest in cooking in counties, such as the UK, which holds especially good for young people. However, the decadence of home cooking did not prove irreversible, and the pandemic marked the end of the negative trend, whose persistence had translated into the demise of the old habit, and paradoxically enhanced the viability of consumption at restaurants and other facilities in the same format. Yoon (2020) reported a 66\% decrease in restaurant sales over the course of a single week in March in the US. Although smaller, the decline still stood at an impressive $48 \%$ in the following month (Yoon, 2020). In China, restaurants fared far worse as their sales declined by $95 \%$, and neither were car sales in a better shape, with a $92 \%$ fall in rate (Rezaei, 2021). India comes close to matching this impact in the restaurant sector, if not overshooting the rate, since Debt (2020), who citing the National Restaurant Association of India, put the cumulative loss 
of local restaurants at an estimated $\$ 9$ billion in the pandemic year (cited in Goyal \& Gupta, 2020). This cross-country variability in impact is likely due to the nature of the response determined by the political model of the state and the democracy index, as China seems to have managed to activate the level of discipline not enjoyed in the West, where people are used to exercising constitutional freedom. In addition, the religion-driven culture of obedience and the face-saving personal imperative is likely to have facilitated the observation of state-sanctioned regulations by the residents. In any case, the pan-global downward consumption spiral could be associated directly with the virus whose eradication should reboot the interest of restaurant-goers. There is empirically backed substance to this belief as Williamson (2020) found that $45.87 \%$ of respondents expressed intense unwillingness to resort to in-seat dining until a vaccine was endorsed and rolled out.

Yet, aside from indicating the impact of restrictions, the decline can also be symptomatic of the acquisition of cooking skills by Americans, which is what presents a reason for concern. Hence, the curve may not change its trajectory much, since the pandemic created an opportunity for people to dust off their mothballed cooking habits and master the art of cooking. Since many individuals who were reluctant to cook or who procrastinated mastering cooking embraced the routine, there is the possibility of at least some restaurants facing an existential threat. A survey performed by Hunter, a food and beverage marketing communications firm, and cited by Yoon (2020) reported 54\% of Americans to be cooking more. The results were compared with behavioral trends prior to the COVID-19 outbreak (Yoon, 2020). The comparison also showed that the baking frequency increased by $46 \%$ (Shoup, 2020). As such, one could dismiss this figure, which is too generalized, but it may include respondents who cook nowadays, not being able to afford going to restaurants owing to financial struggles induced by the pandemic. Alternatively, they could find themselves compelled to sit at home because of the lockdown, or they can work from home without eating at restaurants adjacent to their offices, being relevant. Hence, the removal of these factors can cause these consumers to return to restaurants. Still, optimism aside, cooking can have been found too enjoyable for the routine to be ditched. Although Williamson (2020) predicted a 10\% increase in the intention to cook more meals at home, this figure may fall short of the likely number of home cooking enthusiasts. Hunter's survey, which was cited by Yoon (2020) found that $35 \%$ of respondents derived pleasure from cooking more than ever before. Shoup (2020) raised the share of those enjoying the routine to $73 \%$, also adding that the kitchen-based confidence of $75 \%$ had mounted, which could be due to $50 \%$ being able to learn more about cooking. Given these positive dynamics, if the number of cooking enthusiasts should increase by thrice its current number without declining, restaurants could face adverse repercussions (Yoon, 2020). In fact, upwards of $51 \%$ of those who were cooking more expressed their resolve to persist with the habit even once the crisis was over, which may be due to the 
benefits that cooking has to offer, including money saving, healthy eating, experimenting, and relaxation acknowledged by $58 \%, 52 \%, 50 \%$, and $50 \%$ of the respondents, respectively (Shoup, 2020). The overall sentiment is not surprising, as eating with family and cooking tends to become a new entertainment activity, with coffee shops and restaurants closed down, as follows from Qataris' perception of this new pastime (Ben Hassen et al., 2020), which seems a universal rather than a location-specific trend.

The development of an interest in cooking does not necessarily emerge uninduced. In fact, the mechanism of operant conditioning might be at work that could drive even adults to adopt the rewarding behavior of routinely cooking, and to keep practicing it even after the pandemic ends. Kratcoski (2018) explained this mechanism as a method of learning, which takes place via punishments and rewards for behaviors, and an association is believed to be built between certain behaviors and the results that ensue. The behavior modification concept follows the underlying scholarly principle of cause and effect. Individuals learn that specific behaviors will result in either a negative or positive outcome, based on their past experience of known repercussions (Kratcoski, 2018). A positive outcome or reinforcement could be tangible or otherwise. When intangible, it could come in the shape of an approving look or praise (Vito et al., 2006), and this may be what could follow when the skills relating to mastery of home cooking are put to good use. Gaining the praise of family members encourages the person cooking to adopt this routine, only if it retains the ability to elicit approval and praise. To make certain that they do master culinary skills and gain a praise-winning level of mastery, people forced into quarantine can learn from the best. When they do, the process is compatible with the major postulates of the social learning theory, that according to Edinyang (2016), posits that people can assimilate, master, and replicate new behavior through the observation of others. This adoption is especially likely, when observational experiences are positive and when they contain rewards associated with the behavior (Edinyang, 2016). While watching cookery programs on TV, viewers can hear cooks getting a round of applause for their dishes, which could plant the idea in the newly made amateur home cooks' minds that comparable gastronomical success would draw a similar positive response. It spurs their acquisition of skills through observation and subsequent practice during the pandemic period.

This psychological excursus aside, the trends of cooking mastery and enjoyment may transform into actual losses faced by the hospitality sector. Williamson (2020) found that over $50 \%$ of respondents had no intentions of revisiting restaurants in the post-pandemic period. Still, the future picture of the industry status quo is far from simple, as seen in the visiting intention stratification based on facility type that follows. Even if consumers are willing to grace some restaurants with their presence, they will be very selective, as Williamson (2020) showed that the decrease ranged between $4 \%$ and $44 \%$ for food trucks and buffet style facilities, respectively, which caused the study to predict great struggles for 
the latter category of restaurants owing to the shifting desires of their clientele. The other notable popularity losses that could affect the industry in the time to come are quick service, fast-casual, and casual categories, whose pre-pandemic popularity levels are down by $18 \%, 14 \%$, and $13 \%$, respectively. The buffet model is expected to fare the worst since it has entered a strong decline phase despite being characterized by cheapness. The researcher was surprised not to have observed a shift in consumers' intent toward food trucks, since the model offers them the opportunity to either take food home or eat it outside. Instead, fine dining gained in popularity by $8 \%$. Fine dining is an eating style usually occurring at expensive restaurants where particularly good food is served to visitors, often in a formal fashion.

It would be appropriate to interpret these findings, including examining the reasons for the buffet concept now being increasingly shunned, which could be due to the exposure of ready-cooked food to bacteria that could emanate from visitors' sneezing, etc., while helping themselves to some of the dishes left uncovered (see Centers for Disease Control and Prevention (CDC), 2021). Likewise, food trucks too might not conjure up associations of safety, since cramped space may be belied to offer little room to observe all the hygienic standards, despite food being served in the open without there being too many people, rather than in a poorly ventilated room, as is the case in traditional restaurants (see European Centre for Disease Prevention and Control (ECDC), 2020) warning about the danger of poor ventilation as a precondition for transmission of respiratory infections]. By comparison, in the case of fine dining, since the service is elaborate, consumers are likely to be convinced that their food will be safe. However, the probable reason for this category having experienced only a meager increase is because such food service comes at a high price. This tendency arguably comes as no surprise, given the financial impact of the pandemic that is likely to have boosted price sensitivity across the wide spectrum of consumers. This safety-centered way of thinking is likely in the wake of the lethal pandemic, in which contagion is greatly facilitated through non-compliance with the hygiene rules by many. This factor is likely to be all-important, since despite the cheapness of buffet-style facilities, the concept has not been spared even at the current juncture of financial uncertainty. Thus, it has become the signature feature normally drawing specific consumers to an undesired bargain. Williamson (2020) was so pessimistic regarding the buffet model that neither food maintenance at safe temperatures nor sneeze guards are believed to be capable of enhancing the perception of this model as safe. Furthermore, this study refrained from speculating about the dining public's potential returns on the risk-averse clusters, while the respective prediction was consigned to the industry and academics, as such, who could attempt to answer the question.

Overall, it is worth noting that these changes in values acting as consumption behavior determinants have altered the position of consumer needs in the respective hierarchy. Jung et al. (2015) opined based on Maslow's hierarchy of 
needs, that by virtue of comprising the heart of physiological needs (the topmost tier of the pyramid), food stands as the main choice-shaping factor, with price and service quality being secondary. The next comes safety, as the second tier (cited in Hsu et al., 2018). Love and esteem represent the third and fourth tiers of needs, respectively (Hsu et al., 2018). Hence, it could be that safety has gained supremacy in the wake of the pandemic, and health fears have been instilled into consumers, which has put more crowded restaurants with perceived lower hygiene standards on the margin of the gastronomical landscape. However, the hierarchy of needs may not be an undisputable navigator, as its tiers can be uneven in terms of need seniority/relevance, with observable demographic differences. Voon (2012), who studied various kinds of restaurants arrived at the conclusion that service quality was a key determinant in restaurant choice, which holds good for young consumers as it is regarded as a way of being respected, although food quality was also stressed by this consumer cluster, as in the case of fine dining restaurants (cited in Hsu et al., 2018). With this finding in view, it would be rational to opine that the shift in consumer behavior related to choosing the restaurant type is likely to be demographically variable, as youth seek respect ensured by food quality. This driver is focal for younger consumers, since they are yet to achieve a standing in society, as well as the financial means that will command respect. Hence, restaurant-based quality makes them feel that they are esteemed and serves as a compensatory factor. However, the question is whether younger consumers will be able to afford fine dining, particularly since the crisis seems to have curbed financial opportunities for many. Even if youngsters are preferred by businesses for positions, in an effort to save funds amidst operational uncertainties where the lack of experience will not send the stock falling, yet, they will not be entitled to significant salaries that would suffice to pay for fine dining.

One of the studies, however, has presented results that seem to cast doubts even on the viability of fine dining, while simultaneously offering a glimmer of hope to cheaper restaurant options. Madeira et al. (2020) referred to the stance of numerous famous entrepreneurs and chefs, including Martin Berasategui, the owner of a three-star Michelin restaurant in Spain, who had voiced their concerns about reopening, since they expect a lack of clients owing to the anxiety about visiting facilities. Although Berasategui (2020) has ranked the fear of return to restaurants as the biggest challenge to be overcome by consumers (cited in Madeira et al., 2020), this obstacle is not insurmountable. José Avillez (2020), a top-profile chef in Portugal heading Belcanto, a local two-star Michelin restaurant, that employs 500 workers in its different restaurants, warned that recovery would be a matter of a long time (cited in Madeira et al., 2020). While variable spatially across consumer groups and the willingness to pay is expected to increase by $6 \%$ in the post-pandemic period (Pope, 2021), Klein (2021) has offered an even more optimistic forecast, suggesting that customers' bills will climb to twice their pre-pandemic value, given that the respective businesses are 
maintaining high standards of cleanliness.

Hence, on the path to recovery, safety of the services will play an essential role. The survey results cited by Klein (2021) showed that sanitization standards ranked fourth, whereas prices ranked tenth. Pope (2021) seems even more convinced when it comes to supremacy of cleanliness within the set of consumer values guiding buying decisions, and reported that with the rotation of consumers' values, sanitation and cleanliness would transition to the top of the hierarchy of choice factors in terms of importance. With this change, the price of menu items as a factor has been ousted (Pope, 2021). Still, industry professionals, such as chefs, consider prices an essential factor, and rightfully so, given the financial impact of the pandemic on people's welfare and the corresponding uncertainty, that usually stimulates saving behavior. Restaurants can further boost the perception of service safety by going cyber and arranging deliveries. Brewer and Sebby (2021), who assessed the impact of online restaurants' menus on consumers' buying intentions, indicated that the information and visual appeal of such menus played a key role in consumers' intentions, especially when they perceived the COVID-19 risk. The convenience of online food ordering and the desire for food has a direct influence on consumers. This stance is concordant with earlier findings, including by Dixon et al. (2009) of growing online food ordering popularity being partly driven by precision, speed, and ease of the method (cited in Brewer \& Sebby, 2021). This trend does not suggest that the price factor falls into commercial oblivion. For a restaurant to discount its way into consumers' minds and eventually to keep them interested, could follow, according to Chef Joan Roca (2020)-head of El Celler de Can Roca, a restaurant in Spain with three Michelin stars-who considers that these businesses will be better off reconsidering the business model and providing low-priced menus if they are to survive (cited in Madeira et al., 2020). According to Brehaut (2020), some restaurants have already adapted to new operational conditions. One such instance is Noma-a two-star Michelin restaurant in Denmark owned by Chef René Redzepi and once regarded as the world's best restaurant-that has transformed itself into a wine bar selling hamburgers, for no reason other than to survive (cited in Madeira et al., 2020).

\subsection{Existentialism and the Change of Values-Consumerism No More?}

The lack of good food may eventually help individuals to shed the existential crisis that has crept in, which has its own negative consumption implications. Blough and Brazeau (2021) associated COVID-19 altering people's lives, with an existential crisis of American society that is expected to drag on for years to come. Shiraev (2016) explained an existential crisis as a period when individuals question the foundations of their life, asking whether their lives have any value, purpose, or meaning. When life is believed to lack purpose or meaning, the concept of existential nihilism is also applied, which Bates (2016) associated with 
Friedrich Nietzsche, who correlated existential suffering with the loss of control and powerlessness. Blough and Brazeau (2021) suggested that after experiencing an existential crisis, individuals are unlikely to revert to old norms. Ducharme (2020) arrived at a similar conclusion on COVID-19 having sourced a value-changing existential crisis, drawing an analogy between it and other crises that were said to get people analyzing and modifying their values.

Thus, as averred by Ducharme (2020), subsequent to natural disasters, individuals may grow more religious, which is deemed a coping strategy. Pew Research Center's survey, which accumulated upwards of 3700 answers, reflects the perceived sense of urgency to elicit lessons from the pandemic that are not only practical, such as the importance of wearing masks. The respondents also singled out personal and spiritual lessons, such as believing in the relevance of valuing intimacy and humankind, and praying harder and more often (Ducharme, 2020). While the extent to which this survey is representative is not obvious, its sample was not small, and it does point to the wake-up call provided by the pandemic that seems to mark the shift of values towards greater religiosity and interpersonal relations, rather than consumption. Thus, change can eventually become a value or norm as essential as consumerism, that Prabhu (2021) defined as an economic and social order which encourages and supports the purchase of services and commodities in ever-rising amounts. The researcher also used the concept of crazy consumerism, as if to show, that the philosophy has grown out of proportion, becoming a near-cultic obsession. In its stead may come values and philosophies, such as the ascetic way of living and minimalism, which Watanabe (2020) has defined as promoting the things one values the most and removing everything that distracts one from what is important.

It is now essential to respond to these findings. While one could expect people to lose interest in more extravagant and less practical categories of goods, such as luxury items, yet, its buyers stem from the wealthy social stratum that seems unaffected by the virus, which makes the change of values less likely in this consumer category. Godfrey (2021) points to the worst wealth gap and the immunity of richer individuals to the financial impact of the pandemic, and Picchi (2021) shows a much-improved financial situation of the rich, with billionaires having grown 54\% wealthier during the depressing COVID-10 period. Instead, an existential crisis could have changed less wealthy individuals' consumption habits in one of the following ways. The crisis of existentialism can see people lose confidence in their power, which can breed skepticism about the future and the need to gain money that is instrumental in buying. Hence, they may forsake buying, for the most part, resorting to minimalism or purpose-driven or selective buying of what is functional and relevant. Furthermore, people may begin to wonder what good it is to act altruistically, if despite buying and distributing goods among the needy, their karma does not improve, and they do not obtain divine protection for being kind. However, if existentialism leads to people becoming more religious, and if this religiosity manifests itself through sharing 
with others, the consumption habit may not suffer. As for the factor's longevity in influencing consumption behaviors, for the most part, one should expect the existential crisis to die down with time, as stressors driving disillusionment and devaluing life vanish or lose intensity with the passage of time.

\section{Discussion}

\section{The Pandemic's Persistence-Is It Enough for a New Habit to Rise? Can Every Consumption Behavior Be Perpetuated?}

As shown in the multiple scenarios above, the behavior of consumers changes in one way or another. The longevity of this change, or rather its permanence, depends on how habitual it becomes. Lally and Gardner (2013) and Wood and Neal (2007) defined habit as a learned action executed with minimal cognitive input (cited in Harvey et al., 2020: p. 3). Behaviorists, such as Hull (1943), Skinner (1938), and Thorndike (1998), indicated that habits developed and gained strength via the repetitions of reinforced responses and associative learning (cited in Harvey et al., 2020: p. 3), while cognitive scholars, such as Schneider and Schiffrin (1977) and Wason and Evans (1974), pointed to the relevance of automaticity in habit formation (cited in Harvey et al., 2020: p. 3). One of the studies that dwelt on this aspect measured the median time needed for one to develop a habit. Lally et al. (2010) provided comprehensive insights into how long it takes for a habit to form. A trial spanning a total of three months involved 96 participants who picked behaviors related to drinking, eating, or other activities to be performed on a daily basis in a single context. Participants reached $95 \%$ of their asymptote of automaticity in periods ranging from 18 to 254 days. Judah et al. (2018) and Keller et al. (2021) confirmed the same duration range, whereas Lieber (2016) pointed to the likelihood of the same share of habit formation. Hence, there is a great deal of variation in the time required for individuals to reach their automaticity limits, which can turn out to be very time-consuming (Lally et al., 2010). However, the media period of habit establishment stands at 66 days, according to $\mathrm{Au}$ (2012), Dean (2013), and Protzman et al. (2017), and Keller et al. (2021).

It is important to note that there are a range of factors determining the likelihood of habit acquisition. Verplanken (2006) indicated that a higher level of automaticity could be achieved by simpler behaviors, as compared with complex ones (cited in Lally et al., 2010: p. 1000), which resembles the finding of Chen et al. (2020), who differentiated between easy and more complex tasks that could take up to 18 and 254 days, respectively. Since none of the behaviors presented qualify as complex ones (e.g., buying), the odds of habit development should be higher, and it could be considered as another essential determinant of habit formation. According to Lally et al. (2010), omissions also serve as an essential determinant of habit formation. While it was found that missing a single opportunity for behavioral performance did not materially influence the process of 
habit establishment, James (1890) asserted that habit acquisition was about uninterrupted performance (cited in Lally et al., 2010: p. 1000). Others who virtually did so were: Bhatia (1973), who stressed the importance of an uninterrupted continuity of performance as a way of boosting a specific behavior mode, Dudley and Goodson (1986), who linked habit strengthening directly to uninterrupted repetition, and Miller (2003), who mentioned the need for uninterrupted and regular repetition of acts. Yet, Lally et al. (2010) doubted the feasibility of the criterion of habit formation in the real world, claiming that at almost all times there are occasions when the behavior is not performed. This attitude somewhat resembles the skepticism of Wood and Rünger (2016), who claimed that habits might not take shape with complex tasks, in which different response choices result in different rewards.

Even so, individuals tend to develop habits regardless of the circumstances (Lally et al., 2010). Still, interruptions cannot be overly frequent or extensive; else, individuals are likely to be hard-pressed to acquire any given habit. This presumption makes sense, as Armitage (2005), who reported the results of a study that examined the acquisition of exercise habits over a period of three months, found behavior performance lapses to be negative predictors of future performance, when behavior was evaluated in weekly blocks, although a lapse implies non-visiting for a seven-day time (cited in Lally et al., 2010). This lapse-based finding is concordant with the stance of other researchers, including Teta and Teta (2016) and Straza (2017) regarding loop interruption as central to habit disruption. Hence, the duration of the lapse in habit performance played a role as it spanned as many as seven days. Still, unlike exercising, which is not all too critical, meeting a basic physiological need like eating is more essential. Since restaurants had forcedly been stop short of meeting their customers' needs of being fed, people were forced to switch back to home cooking without the habit being discontinued. The habit formation scenarios inspected earlier, deserve examination in terms of habit formation in a more elaborate way. Moreover, uninterrupted repetition is not the sole determinant of habit establishment, as NIH News in Health (2012) showed that enjoyable or good events could also launch the reward centers of the brain, thereby giving rise to a habit eventually. According to Carter (2019), the reward is the third element of the habit loop, alongside a cue and a routine. Satisfied, the reward gets the brain to remember the loop (Carter, 2019), and a positive reward in the shape of praise or improved familial relations that may follow. For example, as a result of cooking mastery, may do away with the need to repeat the action scores of times for a habit to arise.

In the case of the pandemic, while some people might develop habits, such as home cooking, in the space of 18 days, others would not have done so until 254 days, after the onset of the routine activity got repeated, without significant interruptions. In the context of the pandemic, it implies that lockdowns that often are not overly extensive will lead only some consumers to develop the complete 
habit of home cooking. Many others may have the formation process disrupted by the reopening of these businesses, which can tempt them to revisit, which they will do, depending upon their household's financial health. Since reinforced responses along with associative learning repetitions are involved, classical and operant conditioning may be at work, since positive associations with a neutral stimulus of a new consumer choice and positive reinforcement via the intangible reward of praise, for example, could be the habit development and strengthening ways singled out by the behaviorists.

Overall, the imposition of restrictions that paved the way for the development of habits, such as home cooking, was uneven, being determined by the epidemiological state of affairs. In other words, restrictions interfering with consumers' ability to frequent restaurants, for example, will be lifted every now and then in different countries, and it is likely to be even more, in economies dominated by the service sector, which normally leads to gross underperformance when arrested by domestic clientele and foreign visitors' poor or nonexistent mobility. Hence, in more service-oriented economies whose individual status was determined by the dearth of natural endowments (resources) and/or the limited ability to deploy smokestack industry facilities, the frequency of removing restrictions on the operational capability of restaurants is likely to have been higher, and this interruption of restrictions should keep local residents from having habits become deep-seated or permanent. Further, the financial factor should not be overlooked, as uncertainty and income loss/contraction cannot but influence habits, regardless of how uninterrupted the operational restrictions are. Thus, closedowns are not solely responsible for contributing to the uninterrupted nature of the cooking habit, given the potency of the financial factor, which presumes that the habit in question is unlikely to go if the uninterruptedness of its performance is to be considered as a habit formation factor/mechanism. When it comes to the watching/reading habit related to the apocalyptic genre that sometimes borders on the horror category, non-interruption, may be the reason for the consumption habit and preference shift not to become permanent unless external stressors abate, thereby rendering it less necessary for one to be watching/reading such content. If people find enjoyment therein, aside from the imperative of emotional adjustments, that may cause them to consume the cinematic and literary genre, the lack of emotional disturbance will not lead to their abandoning their consumption habits. However, if present, it will doubly prompt consumers to ramp up their reading or watching of the respective genre. In fact, at times, one cannot help but wonder, if some people are particularly keen on seeing others develop habits during the pandemic, such that they disregard the pleas of healthcare regulators and agencies by walking around unmasked or throwing crowded parties at their mansions. This situation calls for restrictive measures to return, be they lockdowns or other limitations, feeding the relevance of the repetition of routine actions necessitated by the pandemic and its threats, pending habit emergence, which can be that of cooking. 


\section{Conclusion}

Hence, this study's aim to examine the type of changes in the consumer behavior induced by COVID-19 has been achieved, with the following set of findings.

The COVID-19 pandemic has proven to be impactful, as seen in the changes in consumer behavior. Predictably, one of the changes has been the activation of the saving mode, which seems to be induced by financial uncertainty and the actual loss of welfare sources. While it is presumed that the saving behavior will go away, it is doubtful that it will disappear in the foreseeable future, not only due to the difficulties faced by countries to gain a proper vaccination pace, but also because economies have been dealt a heavy blow. This setback creates a disbalance between the job demand and job offers and provides a fertile ground for pay abuse on the part of employers. Hence, the disappearance of saving behavior is contingent on the success of COVID-19 eradication and economic recovery, which should drive a perceptual change in financial security. A somewhat surprising finding was that some people venture to spend much, which has certain therapeutic or coping benefits; yet, this behavioral trend is characteristic of materialistic individuals who are intent on the acquisition of material assets. One does not necessarily have to be materialistic to mass-consume in the pandemic as consumers have switched increasingly to the apocalyptic genre in media and literature, as if aware of its cathartic or therapeutic effects. In fact, people are unlikely to have such knowledge unless experts or all-round binge eaters provide it. Most likely, noticing the relief that comes with reading books in that genre or watching movies and/or TV series of the same genre, people develop their individual preferences (owing to the classical conditioning mechanism of forming positive associations with what is watched/read), at least pending its relevance (based on the persistence of the virus), in a bid to gain the much-needed relief from stress and other negative emotions. TV content may also lead people to learn in the social context and develop their cooking habits, particularly given its rewarding benefits, which can leave restaurants struggling over a decrease in consumption that can also occur if disillusionment results from an existential crisis and the subsequent loss of a perceived life purpose results in a poor money-earning enthusiasm. The study's major findings:

Overall, behavioral change patterns involve a change in terms of category preferences, buying intensity (including loss of buying enthusiasm due to an existential crisis, and/or the saving imperative), and the transition of people to the status of product producers (restaurant services replace home cooking).

In many cases, stressors are the major reason for the change to be accompanied by limitations, barring access to services. Hence, their removal will strip the new consumption trend of its relevance (e.g., saving and cooking can lapse into irrelevance after the economy recovers and the lockdown is lifted).

Still, operant and classical conditioning can ensure the retention of some habits due to their rewarding nature and positive associations, the latter signaling the likelihood of achieving the desired results. 
Some of the habits may also persist regardless of determinants and benefits, given that habits reach automaticity if repeated more than several scores of times, although the acquisition odds vary markedly. Hence, time is likely to wipe out some of the newfound habits, yet chances are that some could stand the test of time.

At this point, to understand whether changes in consumer behavior are a short-term exemption of the norm or mirror a lasting change, companies will fare better by carefully analyzing the reasons for changes in their revenues and the possibility of changes in consumer behaviors having a lasting effect. Doing so will facilitate making accurate day-to-day and long-term strategic decisions, without suffering losses in what has become a volatile and somewhat poorly predictable operational environment.

That COVID-19 has an impact on the economies and consumer behavior became obvious. This research structures and analyzes existing data to the answer the important question: Will the changes in consumer behavior last and therefore force businesses to reconsider their business models, or will these changes be temporary. When it comes to research limitations and future research avenues, the findings seem contrary to major limitations, including the relative deficit of quality sources encountered in the course of this study. Since there is a clear deficit of studies that focus on diverse consumption patterns, it has incentivized the current research design, which in turn, would stimulate further research efforts to present an exhaustive picture of consumption in the postCOVID-19 scenario. Cross-country behavioral comparative studies, if conducted, would further enrich the body of scholarly literature, particularly if the countries analyzed represent different clusters of states based on economic and other indices. Such a focus and its business implications could do much to facilitate the operation of businesses seeking practical applications of research findings. It is this outcome that underscores this study's importance, and which could help navigate the operational vector of businesses by predicting consumer behaviors through interpretations of the experts' findings and forecasts. This approach would allow businesses to wisely allocate what are sometimes fastshrinking resources, without laying off their personnel and failing to contribute to the health and restoration of economies. In addition, this diverse perspective could stimulate the replication of the research design by other researchers and the further enrichment of scholarly discourses.

\section{Conflicts of Interest}

The author declares no conflicts of interest regarding the publication of this paper.

\section{References}

Arias, J. P., Bronfman, N. C., Cisternas, P. C., \& Repetto, P. B. (2017). Hazard Proximity and Risk Perception of Tsunamis in Coastal Cities: Are People Able to Identify Their 
Risk? PLoS ONE, 12, e0186455. https://doi.org/10.1371/journal.pone.0186455

Atalay, A. S., \& Meloy, M. G. (2011). Retail Therapy: A Strategic Effort to Improve Mood: Retail Therapy. Psychology \& Marketing, 28, 638-659.

https://doi.org/10.1002/mar.20404

$\mathrm{Au}$, O. (2012). Study Habits for Hybrid Learning. In S. K. S. Cheung, J. Fong, L. F. Kwok, K. Li, \& R. Kwan (Eds.), International Conference on Hybrid Learning (pp. 265-273). Springer. https://doi.org/10.1007/978-3-642-32018-7 25

Barlow, P., van Schalkwyk, M. C., McKee, M., Labonté, R., \& Stuckler, D. (2021). COVID-19 and the Collapse of Global Trade: Building an Effective Public Health Response. The Lancet Planetary Health, 5, e102-e107. https://doi.org/10.1016/S2542-5196(20)30291-6

Bates, A. T. (2016). Addressing Existential Suffering. BC Medical Journal, 58, 268-273.

Baumeister, R. F., \& Leary, M. R. (1997). Writing Narrative Literature Reviews. Review of General Psychology, 1, 311-320. https://doi.org/10.1037\%2F1089-2680.1.3.311

Ben Hassen, T., El Bilali, H., \& Allahyari, M. S. (2020). Impact of COVID-19 on Food Behavior and Consumption in Qatar. Sustainability, 12, Article No. 6973. https://doi.org/10.3390/su12176973

Berkley, R. A., \& Kaplan, D. M. (2019). Strategic Training and Development. SAGE Publications, Inc.

Bhatia, H. R. (1973). Elements of Educational Psychology. Orient Blackswan.

Blough, E. R., \& Brazeau, G. A. (2021). Confronting the "Brutal Facts" and Identifying Opportunities as Pharmacy Education Weathers the COVID-19 Pandemic. American Journal of Pharmaceutical Education, 85, Article No. 8422.

https://doi.org/10.5688/ajpe8422

Brewer, P., \& Sebby, A. G. (2021). The Effect of Online Restaurant Menus on Consumers' Purchase Intentions during the COVID-19 Pandemic. International Journal of Hospitality Management, 94, Article ID: 102777. https://doi.org/10.1016/j.ijhm.2020.102777

Cariappa, A. G. A., Acharya, K. K., Adhav, C. A., Sendhil, R., \& Ramasundaram, P. (2020). Pandemic Led Food Price Anomalies and Supply Chain Disruption: Evidence from COVID-19 Incidence in India. SSRN Electronic Journal. https://doi.org/10.2139/ssrn.3680634

Carter, J. (2019). The Life and Faith Field Guide for Parents: Help Your Kids Learn Practical Life Skills, Develop Essential Faith Habits, and Embrace a Biblical Worldview. Harvest House.

Centers for Disease Control and Prevention (CDC) (2021, June 14). Restaurant and Bar. U.S. Department of Health \& Human Services.

https://www.cdc.gov/coronavirus/2019-ncov/community/organizations/business-empl oyers/bars-restaurants.html

Chen, W., Chan, T. W., Wong, L. H., Looi, C. K., Liao, C. C. Y., Cheng, H. N. H., Wong, S. L., Mason, J., So, H.-J., Murthy, S., Gu, X., \& Pi, Z. (2020). IDC Theory: Habit and the Habit Loop. Research and Practice in Technology Enhanced Learning, 15, Article No. 10. https://doi.org/10.1186/s41039-020-00127-7

Christelis, D., Georgarakos, D., Jappelli, T., \& Kenny, G. (2020). The COVID-19 Crisis and Consumption: Survey Evidence from Six EU Countries. SSRN Electronic Journal. https://doi.org/10.2139/ssrn.3751097

Chronopoulos, D. K., Lukas, M., \& Wilson, J. O. S. (2020). Consumer Spending Responses to the COVID-19 Pandemic: An Assessment of Great Britain. SSRN Electronic Journal. https://doi.org/10.2139/ssrn.3586723 
Coffey, C., Doorley, K., O’Toole, C., \& Roantree, B. (2020). The Effect of the COVID-19 Pandemic on Consumption and Indirect Tax in Ireland. Budget Perspectives, The Economic and Social Research Institute (ESRI). https://doi.org/10.26504/bp202103.pdf

Credit Suisse (2020). Research Institute: What Will Last? The Long-Term Implications of COVID-19. Credit Suisse.

Dastagiri, M. B. (2019). Global Agricultural Revolutions, Trade, Policies, and Vision. Cambridge Scholars Publishing.

Dastin, J., \& Rana, A. (2021, April 29). Amazon's Sales and Profit Rise as Retailer Rides Wave of Pandemic Shopping. Reuters. https://www.reuters.com/technology/amazon-first-quarter-sales-beat-expectations-202 1-04-29/

Davenport, A., Joyce, R., Rasul, I., \& Waters, T. (2020). Spending and Saving during the COVID-19 Crisis: Evidence from Bank Account Data. Institute for Fiscal Studies.

Dean, J. (2013). Making Habits, Breaking Habits: Why We Do Things, Why We Don't, and How to Make Any Change Stick. Hachette Books.

Del Rio, C., Collins, L. F., \& Malani, P. (2020). Long-Term Health Consequences of COVID-19. The Journal of the American Medical Association, 324, 1723-1724. https://doi.org/10.1001/jama.2020.19719

Ducharme, J. (2020, December 29). Why the COVID-19 Pandemic Has Caused a Widespread Existential Crisis. Time. https://time.com/5925218/covid-19-pandemic-life-decisions/

Dudley, G. W., \& Goodson, S. L. (1986). The Psychology of Call Reluctance: How to Overcome the Fear of Self-Promotion. Behavioral Science Research Press.

Edinyang, S. D. (2016). The Significance of Social Learning Theories in the Teaching of Social Studies Education. International Journal of Sociology and Anthropology Research, 2, 40-45.

European Centre for Disease Prevention and Control (ECDC). (2020, June 22). Heating, Ventilation and Air-Conditioning Systems in the Context of COVID-19. European Centre for Disease Prevention and Control.

https://www.ecdc.europa.eu/sites/default/files/documents/Ventilation-in-the-context-o f-COVID-19.pdf

Ferguson, C. J. (2010). Violent Crime: Clinical and Social Implications. Sage. https://doi.org/10.4135/9781483349305

Financial Stability Board (FSB) (2020, April 15). COVID-19 Pandemic: Financial Stability Implications and Policy Measures Taken. Financial Stability Board. https://www.fsb.org/wp-content/uploads/P150420.pdf

Gamerman, E. (2020, March 11). Readers Binge on Books about Pandemics (Really). Wall Street Journal (Eastern Ed.).

https://www.wsj.com/articles/readers-are-bingeing-books-about-pandemics-really-115 $\underline{83944988}$

Ger, G., \& Belk, R. W. (1996). Cross-Cultural Differences in Materialism. Journal of Economic Psychology, 17, 55-77. https://doi.org/10.1016/0167-4870(95)00035-6

Gitimu, P. N., \& Waithaka, A. G. (2019). Retail Therapy: Influence of Life Engagement and Subjective Happiness. Journal of Behavioral Studies in Business, 10, 1-12.

Glassman, J. (2021, March 2). The Return of Consumer Spending. J.P. Morgan. https://www.jpmorgan.com/commercial-banking/insights/the-return-of-consumer-spe nding 
Godfrey, N. (2021, May 17). The Pandemic Has Worsened the Wealth Gap. Kiplinger. https://www.kiplinger.com/personal-finance/602801/the-pandemic-has-worsened-thewealth-gap

Goyal, M. K., \& Gupta, A. K. (2020). Integrated Risk of Pandemic: COVID-19 Impacts, Resilience, and Recommendations. Springer Nature.

Hamonic, W. G. (2017). Global Catastrophe in Motion Pictures as Meaning and Message: The Functions of Apocalyptic Cinema in American Film. Journal of Religion \& Film, 21, Article No. 36.

Hannon, P. (2021, May 2). COVID-19 Savings Stockpile Could Accelerate Economy-If Consumers Spend It. Wall Street Journal (Eastern Ed.).

https://www.wsj.com/articles/covid-19-savings-stockpile-could-accelerate-economyif-c onsumers-spend-it-11619967601

Harvey, A., Callaway, C. A., Zieve, G. G., Gumport, N. B., \& Armstrong, C. C. (2020). Applying the Science of Habit Formation to Evidence-Based Psychological Treatment: Improving Outcomes for Mental Illness. Perspective in Psychological Sciences. (In Press) https://doi.org/10.31234/osf.io/qma4f

Helfgott, J. B. (2018). No Remorse: Psychopathy and Criminal Justice. ABC-CLIO.

Hsu, S.-H., Hsiao, C.-F., \& Tsai, S.-B. (2018). Constructing a Consumption Model of Fine Dining from the Perspective of Behavioral Economics. PLoS ONE, 13, e0194886. https://doi.org/10.1371/journal.pone.0194886

Hua, L. L. (2018). The Yin Yang Guide to Weight Loss-Lose Weight through the Balance and Harmony of the Ancient Chinese Tradition of Yin and Yang. John Blake Publishing.

Jin, X., Zhao, Y., Song, W., \& Zhao, T. (2021). Save for Safe: Effect of COVID-19 Pandemic on Consumers' Saving and Spending Behavior in China. Frontiers in Psychology, 12, Article No. 636859. https://doi.org/10.3389/fpsyg.2021.636859

Judah, G., Gardner, B., Kenward, M. G., DeStavola, B., \& Aunger, R. (2018). Exploratory Study of the Impact of Perceived Reward on Habit Formation. BMC Psychology, 6, Article No. 62. https://doi.org/10.1186/s40359-018-0270-Z

Keller, J., Kwasnicka, D., Klaiber, P., Sichert, L., Lally, P., \& Fleig, L. (2021). Habit Formation Following Routine-Based versus Time-Based Cue Planning: A Randomized Controlled Trial. British Journal of Health Psychology, 26, 807-824.

https://doi.org/10.1111/bjhp.12504

Kinateder, M. T., Kuligowski, E. D., Reneke, P. A., \& Peacock, R. D. (2015). Risk Perception in Fire Evacuation Behavior Revisited: Definitions, Related Concepts, and Empirical Evidence. Fire Science Reviews, 4, Article No. 1.

https://doi.org/10.1186/s40038-014-0005-Z

Kirsh, S. J. (2019). Parenting in the Zombie Apocalypse: The Psychology of Raising Children in a Time of Horror. McFarland.

Klein, D. (2021, March 9). Guests Will Spend Twice as Much with Clear Restaurants. QSR Magazine.

https://www.qsrmagazine.com/consumer-trends/guests-will-spend-twice-much-clean-r estaurants

Kratcoski, P. C. (2018). Correctional Counseling and Treatment. Springer. https://doi.org/10.1007/978-3-319-54349-9

Kumar, R., \& Abdin, M. S. (2021). Impact of Epidemics and Pandemics on Consumption Pattern: Evidence from COVID-19 Pandemic in Rural-Urban India. Asian Journal of 
Economics and Banking, 5, 2-14. https://doi.org/10.1108/AJEB-12-2020-0109

Lally, P., van Jaarsveld, C. H. M., Potts, H. W. W., \& Wardle, J. (2010). How Are Habits Formed: Modelling Habit Formation in the Real World. European Journal of Social Psychology, 40, 998-1009. https://doi.org/10.1002/ejsp.674

Lee, L. (2015). The Emotional Shopper: Assessing the Effectiveness of Retail Therapy. Foundations and Trends ${ }^{\oplus}$ in Marketing, 8, 69-145. https://doi.org/10.1561/1700000035

Lieber, M. (2016). Implementing Tiny Goals after Current Habits to Create Consistent Healthy Lifestyle Routine. [University of Akron]. Honors Research Projects. https://core.ac.uk/download/pdf/232678957.pdf

Lucken, M. F. (2021). The Binge Watcher's Guide to Riverdale: An Unofficial Companion. Riverdale Avenue Books.

Mack, R. L., \& Ott, B. L. (2010). Critical Media Studies: An Introduction. Wiley.

Madeira, A., Palrão, T., \& Mendes, A. S. (2020). The Impact of Pandemic Crisis on the Restaurant Business. Sustainability, 13, Article No. 40. https://doi.org/10.3390/su13010040

Mattinson, A. (2021). Supermarket Sales Growth Remains at Its Highest Level since June 2020. The Grocer. https://www.thegrocer.co.uk/finance/supermarket-sales-growth-remains-at-its-highest -level-since-june-2020/653975.article

McGuire, K. (2021). COVID-19, Contagion, and Vaccine Optimism. The Journal of Medical Humanities, 42, 51-62. https://doi.org/10.1007/s10912-021-09677-3

Miller, C. E. (2003). Ordained to Preach: A Theology and Practice of Preaching. Wipf \& Stock Publishers.

NIH News in Health (2012, January). Breaking Bad Habits: Why It's So Hard to Change. National Institutes of Health: Department of Health and Human Services. https://newsinhealth.nih.gov/sites/nihNIH/files/2012/January/NIHNiHJan2012.pdf

O’Connell, M., De Paula, A., \& Smith, K. (2020, November 4). Spending Dynamics and Panic Buying during the COVID-19 First Wave. VoxEu CEPR.

https://voxeu.org/article/spending-dynamics-and-panic-buying-during-covid-19-firstwave

Ozili, P. K., \& Arun, T. (2020). Spillover of COVID-19: Impact on the Global Economy. SSRN Electronic Journal. https://doi.org/10.2139/ssrn.3562570

Picchi, A. (2021, March 31). Billionaires Got 54\% Richer during Pandemic, Sparking Calls for "Wealth Tax". CBS News.

https://www.cbsnews.com/news/billionaire-wealth-covid-pandemic-12-trillion-jeff-bez os-wealth-tax

Pope, R. (2021, March 9). Recent Study Reveals That Restaurants' Sanitation Standards Now Influence Consumer Purchase Behavior More than Price of Menu Items. Simon-Kucher \& Partners.

https://www.simon-kucher.com/en/about/media-center/recent-study-reveals-restauran ts-sanitation-standards-now-influence-consumer-purchase-behavior-more-price-men $\underline{\mathrm{u}-\mathrm{items}}$

Prabhu, T. L. (2021). Environmental Ecology: Fundamental Concepts of Environmental Ecology. Nestfame Creations.

Protzman, D., McNamara, J., \& Protzman, C. (2017). One-Piece Flow vs. Batching: A Guide to Understanding How Continuous Flow Maximizes Productivity and Customer Value. Productivity Press. https://doi.org/10.1201/b19070 
Rezaei, N. (2021). Coronavirus Disease-COVID-19. Springer International Publishing. https://doi.org/10.1007/978-3-030-63761-3

Shiraev, E. (2016). Personality Theories: A Global View. SAGE Publications. https://doi.org/10.4135/9781483399256

Shoup, M. E. (2020, April 15). Survey: Cooking More at Home Could Become the New Normal Post-Pandemic. Foodnavigator-Usa.Com; William Reed Business Media Ltd. https://www.foodnavigator-usa.com/Article/2020/04/15/Survey-Cooking-at-home-will -become-the-new-normal-post-pandemic

Sperling, N. (2020, March 4). “Contagion”, Steven Soderbergh's 2011 Thriller, Is Climbing up the Charts. The New York Times.

https://www.nytimes.com/2020/03/04/business/media/coronavirus-contagion-movie.ht $\underline{\mathrm{ml}}$

Srivner, C., \& Christensen, K. (2021). Scaring Away Anxiety: Therapeutic Avenues for Horror Fiction to Enhance Treatment for Anxiety Symptoms. Psyarxiv. (Preprint) https://doi.org/10.31234/osf.io/7uh6f

Straza, E. M. (2017). Comfort Detox: Finding Freedom from Habits That Bind You. InterVarsity Press.

Supriatna, E. (2020). Socio-Economic Impacts of the COVID-19 Pandemic: The Case of Bandung City. Journal of Governance, 5, 61-70. https://doi.org/10.31506/jog.v5i1.8041

Teta, K., \& Teta, J. (2016). Lose Weight Here: The Metabolic Secret to Target Stubborn Fat and Fix Your Problem Areas. Rodale Books.

Torraco, R. J. (2005). Writing Integrative Literature Reviews: Guidelines and Examples. Human Resource Development Review, 4, 356-367. https://doi.org/10.1177\%2F1534484305278283

Tranfield, D., Denyer, D., \& Smart, P. (2003). Towards a Methodology for Developing Evidence-Informed Management Knowledge by Means of Systematic Review. British Journal of Management, 14, 207-222. https://doi.org/10.1111/1467-8551.00375

Verschuur, J., Koks, E. E., \& Hall, J. W. (2021). Global Economic Impacts of COVID-19 Lockdown Measures Stand out in High-Frequency Shipping Data. PLoS ONE, 16, e0248818. https://doi.org/10.1371/journal.pone.0248818

Vito, G. F., Holmes, R. M., \& Maahs, J. R. (2006). Criminology: Theory, Research, and Policy. Jones and Bartlett.

Waitzkin, H. (2020). COVID-19 as Cause versus Trigger for the Collapse of Capitalism. International Journal of Health Services, 51, 203-205. https://doi.org/10.1177\%2F0020731420977711

Watanabe, I. (2020). Minimalism Collection: Minimalism for Beginners, Minimalism for Families and Decluttering. Chronos Publishing LLC.

Williamson, D. (2020). COVID-19 and Consumer Future Restaurant Intentions. Miami University.

Wolf, A. (2014). The XX Factor: How Working Women Are Creating a New Society. Profile Books Limited.

Wood, W., \& Rünger, D. (2016). Psychology of Habit. Annual Review of Psychology, 67, 289-314. https://doi.org/10.1146/annurev-psych-122414-033417

Yoon, E. (2020, May 26). 3 Behavioral Trends That Will Reshape Our Post-COVID World. Harvard Business Review.

https://hbr.org/2020/05/3-behavioral-trends-that-will-reshape-our-post-covid-world 